(C) 1989 ISIJ

\title{
Effect of Water Temperature on Cooling Capacity in Water Cooling of Hot Steels
}

Masashi Mitsutsuka and Keiji Fukuda

\begin{abstract}
Synopsis :
In water cooling of hot steels, a cooling capacity $(H)$ is influenced by water temperature $\left(\theta_{u}\right)$. The authors analyzed the effect of water temperature on the cooling capacity by using the data of authors' and other reseachers' experiments. The coefficient of water temperature $R b\left[{ }^{\circ} \mathrm{C}^{-1}\right]$, which is the contribution factor of water temperature to the cooling capacity, is defined as $R b=\left[H\left(\theta_{b}+\Delta \theta\right)-H\left(\theta_{b}-\Delta \theta\right)\right] /\left[H\left(\theta_{b}\right)\right.$ $\times 2 \cdot \Delta \theta]$, where $\theta_{b}$ and $\Delta \theta$ are basic temperature and temperature difference from $\theta_{b}$, respectively. By introducing the idea of $R b$, the effect of $\theta_{w}$ on $H$ in many experiments has been analysed systematically. The mian results obtained are as follows:

1) The values of $R_{\theta_{b} 5}\left(\theta_{b}: 30, \Delta \theta: 5\right)$, which correspond to the typical temperature of cooling water in production mills, exist within the range of -0.01 to $-0.02^{\circ} \mathrm{C}^{-1}$. This result means that the values of $H$ change $\mp(1$ to 2$) \%$ with $\pm 1^{\circ} \mathrm{C}$ variation of $\theta_{w}$.

2) The absolute $R_{\theta b, 5}$-value of laminar coolings is larger than that of spray coolings.

3) It seems that the values of $R b$ are influenced by sizes and surface conditions of a steel to be cooled, flow conditions of cooling water on a cooled surface, and so on.

Key words : water cooling; cooling capacity; water temperature; hot steel; heat transfer; laminar cooling ; spray cooling.
\end{abstract}

\section{1. 緒 \\ 言}

現在，鋼材熱処理プロセスは，庄延と压延熱を利用す る制御压延・制御冷却（TMCP）化されつつあり，今後 この傾向はますます拡大されるであろう。TMCPを安 定かつ確実に実行するには，鋼材の冷却技術の点では，

(1)高温域における冷却能力の制御, (2)中温域 (300-600 ${ }^{\circ} \mathrm{C}$, 復熱後の値) における冷却停址とその温 度での保定 (等温变態), および(3)高温域冷却中の鋼材

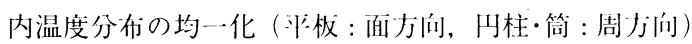
が重要である.

TMCP 用冷却に多用されている水冷の場令，冷却能 力は冷媒側条件と鋼材側条件に影響される。冷媒側条件 のうち水温の寄与割命は, 噴射水量, 冷却面に打ける冷 却水の流動状態などのそれに比べると相対的に小さい が，工場の冷却水温度は長期的（季節変動）および短期 的（ミルの短期的休止:や稼動率の変動）に变動する。 たがつて，ミルの冷却制御式には水温の影響が導人され ている.

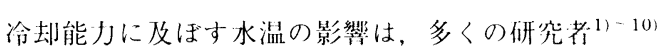
によつて実験的に調べられているが，それぞれの結果は 大幅に相違している。著者らも睤利 30 年代から種々の 目的の水冷実験に際し，水温の影蝗を测起している.

冷却能力に及ほす水温の影響を表す水埧倸数を導人 し，水温の影響を統一的に解析することを武みた。解析 には, 著者らの実験データと公開文献のデータを用いた。 本報年では，水温係数の定義，佃，特性などを就述する。

\section{2. 解 析 方 法}

\section{$2 \cdot 1$ 解析対象範囲}

解析では, TMCP 用水冷，特に熱延ランナウトテー ブル（ROT）と厚极熟処理の水冷をけ対乎にしている ので，原則として，解析对象範讲をT Table 1 のように 限分した。

1 ) 水温の範井: TMCP 用水冷に用いられる冷却水

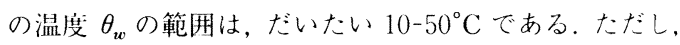
線材や泠延鋼板では温水や沸騰水も用いられているが, これらを解析の対象範囲から除いた。 
2 ) 噴射水星 $W$ の範闸: 熱延 ROT 用水冷や厚板熱 処理用水冷の $W$ の蝺用は,たいたい300-1000

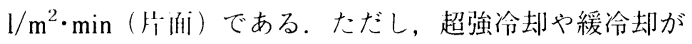
必要な場令には, 上花以外の $W$ も用いられているが, これらを解析の刘象籁用から除いた。

3 ) 龬材の表泊埧度: $\theta_{s}$ : TMCP 用水冷時の $\theta_{s}$ の範用 は,たいたい $900-750^{\circ} \mathrm{C}$ (自然冷却状態)から 600-300 ${ }^{\circ} \mathrm{C}$ (復熱後の储) までである，极厚が大きい場 今, 水冷中の $\theta_{s}$ は $300^{\circ} \mathrm{C}$ 以下まで降下しているケース もあるが，解析では， $\theta_{s}$ の刘象範閁を $500-700^{\circ} \mathrm{C} に$ 限 走した。

4) 龬材の内部温度: 铜材の熱処理分野では, 冷却能 力 $H$ の䘚小法として, 极景力问中央 (以下 $1 / 2 t$ と記述) の $800 \rightarrow 500,800 \rightarrow 300^{\circ} \mathrm{C}$ 䦌などの平均冷却速度 $V$ が 多用されている，Hが $V$ や平均熱伝達係数 れているデータについては, 初期温度 $\rightarrow 500^{\circ} \mathrm{C}$ 間 $(1 / 2 t)$ を解析対象にした。の場命, 水冷中の $\theta_{s}$ は, 鋼材の 厚さと泠却の蜉さに影響されるが， $450-200^{\circ} \mathrm{C}$ 程度まで 降下している。

5 ）銅材の冷却面性状：熱間1:延鋼材は，ホットスト

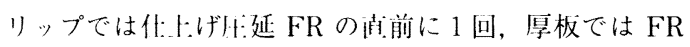
の途中で数叮デスケーリングされる。しかも，FRで新 生酒が出るので, FR 迠後の䤱材表耐の酸化度命いは小 さいが，水冷開始までの放冷期間中に酸化される。この 放冷期間は，ホットストリップでは 1-2 s 程度だが，厚 板では，镃種，板等処理法などによつて異なり 20-100sである.したがつて，水冷ゾーン人側におけ るスケール早さは $10^{0}-10^{1} \mu \mathrm{m}$ のオーダーである.上記 の理けから, 解析に使用するデー夕を高温酸化された試 料を用いて得られたものに限尖した。

6）武料の小法：水冷の場令，鋼材に噴射された冷却 水の鋼材にでの挙動, 換方すれば試料小法も $H$ に影響

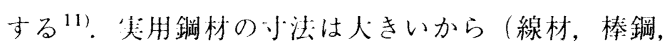
小径管などを除く), 解析に使用するデー夕をある程度

Table 1. The range of experimental conditions used for this analysis.

\begin{tabular}{|c|c|}
\hline Item & Condition \\
\hline Water temperature, $\theta_{w}\left({ }^{\circ} \mathrm{C}\right)$ & 10 to 50 \\
\hline Water flux density, $W\left(\mathrm{l} / \mathrm{m}^{2} \cdot \min \right)$ & 300 to 1000 \\
\hline Cooled surface temperature, $\theta_{s}\left({ }^{\circ} \mathrm{C}\right)$ & 500 to 700 \\
\hline $\begin{array}{l}\text { Temperature range of cooling rate, } V \text {, and, mean } \\
\text { heat transfer coefficient, } \bar{h}\left({ }^{\circ} \mathrm{C}\right)\end{array}$ & $\begin{array}{l}\text { Initial temperature } \\
\text { to } 500(\text { at } 1 / 2 t)\end{array}$ \\
\hline Cooled surface condition & Oxided surface \\
\hline Specimen size (mm) & $\begin{array}{l}\text { Approx. } 50 \text { (Width } \\
\text { or diameter) }\end{array}$ \\
\hline
\end{tabular}

以上大きい試料，すなわち約 $50 \mathrm{~mm}$ 幅または径以上の 試料を用いて得られたものに限定した。

\section{$2 \cdot 2$ 解析に用いた実験と文献}

解析に用いた各実験の主要条件を Table 2 に, 実験 式を Table 3 に示す. 冷却法の記号は, S : スプレー, $\mathrm{L}:$ ラミナ, SL : S + L の複合冷却, I : 浸漬,および $\mathrm{F}$ : 流水を, その他の記号は， M : ミル実験を示す。実 験総数は 17 (ラボ実験 : $13, \mathrm{M}: 4$ ) で,このうち著者 らの実験は 11 である.

Table 2 の2 と L4 の実験には銅試料が用いられて いるが, 加熱温度が高いから, 試料表面は高温酸化され ているものと推定されるので,これらのデー夕を解析に 採用した。流水冷却（F1）の実験では， SUS304 試料 (14t $\mathrm{t} \times 154 \mathrm{w} \times 300 \mathrm{~mm} l$, 表面仕上げ $\left.R_{\text {max }}: 3 \mu \mathrm{m}\right)$ を 電気炉（窑素䨌囲気）で約 $980^{\circ} \mathrm{C}$ に加熱した後，水平 にセットしこの上面に冷却水を流した。ノズルの寸法 は, ギャップ: $2 \mathrm{~mm}$, 幅 : $150 \mathrm{~mm}$ であり, ノズル出口

Table 2. Experimental conditions of the experiments used for this analysis.

\begin{tabular}{|c|c|c|c|c|c|}
\hline No. & Reseacher & $\begin{array}{l}\text { Coolig } \\
\text { methed }\end{array}$ & $\begin{array}{c}\text { Water } \\
\text { temp. } \\
{\left[^{\circ} \mathrm{C}\right]}\end{array}$ & $\begin{array}{l}\text { Specimen } \\
\text { material }^{* 2 \text { ) }}\end{array}$ & $\begin{array}{l}\text { Results } \\
\text { used for } \\
\text { work }^{* 3)}\end{array}$ \\
\hline $\mathrm{S1}$ & Authors ${ }^{11}$ & FCS & $10-35$ & SUS304 & Fig. 1 \\
\hline $\mathrm{S} 2$ & Authors ${ }^{11}$ & FCS & $10-35$ & SUS304 & Fig. 1 \\
\hline S3 & Authors $^{2)}$ & M-J & $4-95$ & LC-steel & Fig. 20 \\
\hline $\mathrm{S} 4$ & Authors $^{2)}$ & M-J & $4-95$ & LC-steel & Fig. 14 \\
\hline $\mathrm{S} 5$ & Authors $^{2) 3 \text { ) }}$ & $\mathrm{FS}$ & $20-80$ & SUS304 & Fig. 13 \\
\hline S6 & KOROTKOV ${ }^{4)}$ & Jet & $20-80$ & C-steel & Fig. 37 \\
\hline S7M & Authors ${ }^{1)}$ & $\mathrm{FS}$ & $27-35$ & LC-steel & Fig. 3 \\
\hline $\mathrm{S} 8 \mathrm{M}$ & Authors & $\mathrm{FS}$ & $24-32$ & C-steel & Original \\
\hline SL1M & Authors ${ }^{1)}$ & $\mathrm{CL}+\mathrm{FCS}$ & $17-42$ & LC-steel & Fig. 4 \\
\hline $\mathrm{Ll}$ & KUNIOKA $^{5)}$ & RL & $15-80$ & LC-steel & Table 2 \\
\hline $\mathrm{L} 2$ & SHIRAIWA $^{6)}$ & S-RL & $20-61$ & Copper & Fig. 10,13 \\
\hline $\mathrm{L} 3$ & Oтомо $^{7)}$ & $\mathrm{S}-\mathrm{RL}$ & $5-50$ & SUS & Eq. 1 \\
\hline $\mathrm{L} 4$ & YANAGil $^{8)}$ & $\mathrm{S}-\mathrm{CL}$ & $10-80$ & Copper & Fig. 15, 16 \\
\hline $\mathrm{L} 5 \mathrm{M}$ & MIYAKE $^{9)}$ & $\mathrm{RL}$ & 45 & LC-steel & Eq. 3 \\
\hline II & Authors ${ }^{10)}$ & I & $23-93$ & LC-steel & Fig. 4 \\
\hline $\mathrm{I} 2$ & Authors ${ }^{10)}$ & 1 & $23-93$ & LC-steel & Fig. 5 \\
\hline $\mathrm{Fl}$ & Authors & WF & $35-80$ & SUS304 & Original \\
\hline \multicolumn{6}{|c|}{$\begin{array}{l}\text { *1) FCS : Full Cone Spray, FS : Flat Spray, M-J : Multiple Jet, CL } \\
\text { : Curtain Laminar, RL: Rod Laminar, S : Single, I : Immersion, } \\
\text { WF : Water Flow } \\
\text { *2) LC : Low Carbon, C : Carbon } \\
\text { *3) The figure, table and equation number here denote that in the }\end{array}$} \\
\hline
\end{tabular}


Table 3. Empirical equations used for this analysis.

\begin{tabular}{|c|c|c|}
\hline Symbol & Equation & $R_{30,5}$ \\
\hline $\mathrm{S} 1$ & 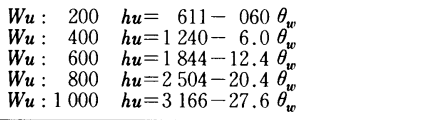 & $\begin{array}{l}-0.0075 \\
I^{\circ} \dot{C}^{-1} \mid \\
(\overline{R b})^{-1}\end{array}$ \\
\hline $\mathrm{S} 2$ & $\begin{array}{lrl}W u: & 200 & h u=659-2.4 \theta_{w} \\
W u: & 400 & h u=1374-10.4 \theta_{w} \\
W u: & 600 & h u=2130-20.0 \theta_{w} \\
W u: & 800 & h u=2914-30.4 \theta_{w} \\
W u: & 1000 & h u=3724-42.4 \theta_{w}\end{array}$ & $\begin{array}{c}-0.0119 \\
(\bar{R} \bar{b})\end{array}$ \\
\hline $\mathrm{S} 3$ & $V=18.43-0.0741 \theta_{w}-1.32 \cdot 10^{-4} \theta_{w}{ }^{2}$ & -0.0051 \\
\hline $\mathrm{S} 4$ & $h=4967-44.0 \theta_{v}+0.128 \theta_{v}{ }^{2}$ & -0.0096 \\
\hline S5 & $\begin{array}{l}W u: 1880 h=3276-19.0 \theta_{w}-0.070 \theta_{w}^{2} \\
W u: 2280 h=3813-8.8 \theta_{w}-0.217 \theta_{w_{2}} \\
W u: 2640 h=3605-47.9 \theta_{w}-0.893 \theta_{w} \\
W u: 2640 h=4351-33.1 \theta_{w}-0.746 \theta_{w}^{w_{w}}\end{array}$ & -0.0048 \\
\hline S6 & $h=1170-8.83 \theta_{v}$ & -0.0098 \\
\hline S7M & $h u=1740-21.2 \theta_{w}$ & -0.0192 \\
\hline $\mathrm{S} 8 \mathrm{M}$ & $h u+h e=1713-19.1 \theta_{v}$ & -0.0168 \\
\hline SL1M & $V=33.39-0.400 \theta_{w}$ & -0.0187 \\
\hline L1 & $\theta_{s}: 600 h \propto\left(100-\theta_{w}\right)^{0.565}$ & -0.0063 \\
\hline $\mathrm{L} 2$ & $\begin{array}{l}r: 0, \theta_{w}: 20-40 \quad q=6.67 \cdot 10^{6}-8.1 \cdot 10^{4} \theta_{w} \\
r: 0, \theta_{w}: 40-60 \quad q=5.79 \cdot 10^{6}-5.9 \cdot 10^{4} \theta_{w} \\
r: 10, \theta_{w}: 21-38 \quad q=9.38 \cdot 10^{6}-18.5 \cdot 10^{4} \theta_{w} \\
r: 10, \theta_{w}: 38-61 \quad q=4.61 \cdot 10^{6}-6.0 \cdot 10^{4} \theta_{w}\end{array}$ & $-\frac{0.0305}{(\overline{R b})}$ \\
\hline L3 & $\theta_{s}: 600 V \propto\left(100-\theta_{w}\right)^{1.85}$ & -0.0264 \\
\hline $\mathrm{L} 4$ & $\begin{array}{ll}l=0 & \log (q)=6.9460-7.69 \cdot 10^{-3} \theta_{w} \\
l=50+100 \log (q)=6.6234-7.95 \cdot 10^{-3} \theta_{w}\end{array}$ & $\begin{array}{c}-0.0180 \\
(\overline{R b})\end{array}$ \\
\hline L5M & $q \propto\left(2.50-1.15 \cdot \log \left(\theta_{w}\right)\right)^{0.645}$ & -0.0135 \\
\hline I1 & $V=27.77-0.168 \theta_{v}-8.11 \cdot 10^{4} \theta_{w}{ }^{2}$ & -0.0098 \\
\hline $\mathrm{I} 2$ & $h=8742-131.0 \theta_{w}+0.484 \theta_{v}{ }^{2}$ & -0.0194 \\
\hline $\mathrm{F} 1$ & $\log (h)=3.8598-0.01612 \theta_{w}$ & $\begin{array}{l}-0.0373 \\
\left(R_{40.5}\right)\end{array}$ \\
\hline
\end{tabular}

*) $R_{30.5}$ denotes the value of $R b$ at $\theta b: 30$ and $\Delta \theta: 5^{\circ} \mathrm{C}$

*2) Suffix $u$ and $l$ denote the upper and lower surface, respectively

における冷却水の流速は $2-5 \mathrm{~m} / \mathrm{s}$ である。試料は，炉 内への浸入酸素と冷却装置への取付け作業中にかなり酸 化された。

\section{$2 \cdot 3$ 冷却能力の表示法}

各実験において, $H$ は熱伝達係数 $h$, 平均熱伝達係数 $\bar{h}$, 熱流束 $q$ または冷却速度 $V$ で表示されている. 内 訳は, $h: 7, \bar{h}: 3, q: 3$ および $V: 4$ である.

データに $\theta_{s}$ が明示されている場合, $h$ と $q$ との間に は ( 1 )式の関係が, 一方 $V$ と $q$ との間には, ( 2$)$ 式 の関係が存在する.

$$
\begin{aligned}
& h=q /\left(\theta_{s}-\theta_{w}\right) \\
& V=\left(\int_{0}^{t} q d t\right) /[Q \cdot t] \\
& t: \text { 水冷時間 }[\mathrm{s}] \\
& Q \text { : 面積当たりの熱容量 }\left[\mathrm{kcal} / \mathrm{m}^{2} \cdot{ }^{\circ} \mathrm{C}\right]
\end{aligned}
$$

したがつて，詳細な実験条件が記載されていれば，各表 示法を統一することは可能である.しかし，今回用いた
データについては, 実験条件の記述が不十分なため,こ の統一化はできなかつた。したがつて，各実験結果の冷 却能力表示法をそのまま解析に用いた。

\section{$2 \cdot 4$ 数式化法}

解析に用いる用語と式を次のように定義した.

1 ）基準水温 $\theta_{b}\left[{ }^{\circ} \mathrm{C}\right]$ と水温差 $\Delta \theta\left[{ }^{\circ} \mathrm{C}\right]$ : ミルの冷却 制御式において，水温 $\theta_{w}$ の影響は，(1) $\theta_{\boldsymbol{w}}$,の值，(2) $\theta_{b}$ からの偏差, (3) $\theta_{w} / \theta_{b}$ の比などの形で導人されている.

解析では, (2)のケースを対象にしたので $\theta_{b}$ を導入した. また, 解析の容易さおよび解析結果のミルへの適用の夋 易さを考慮し， $\theta_{b}$ の值として 20,30 および 40 を， $\theta_{b}$ からの温度差 $\Delta \theta$ の值として, 各ミルの $\theta_{w}$ の变動範囲 を考慮し \pm 5 および \pm 10 を採用した。

2 ) 冷却能力比 $C_{\theta_{\boldsymbol{x}} / \theta_{b}}[$ (一) : 解析に用いた文献の中 には，実験式の定数が記載されていないため，Hの值 を算出できないものがある。また，解析に用いる文献数 を多くするため，Hが $h, \bar{h}, q$ または $V$ で表示されて いる実験結果を採用した。解析に際しては，各実験の奇 与率を同じにし，かつ各実験結果を间一条件で処理する ため, $C_{\theta_{x} / \theta_{b}}$ を導入した. $C_{\theta_{x} / \theta_{b}}$ は，任意水温 $\theta_{x}$ と基 準水温 $\theta_{b}$ のそれぞれに対匛る $H\left(\theta_{x}\right)$ と $H\left(\theta_{b}\right)$ と の比を示し, ( 3 )式のように定義した。

$$
C_{\theta_{x} / \theta_{b}}=H\left(\theta_{x}\right) / H\left(\theta_{b}\right)
$$

3 ) 水温係数 $R b\left[{ }^{\circ} \mathrm{C}^{-1}\right]: R b$ は $\theta_{w}$ の変動に対する $H$ の変化割合を示し，（４)式のように㳬義した．

$$
R_{b}=\frac{\left[H\left(\theta_{b}+\Delta \theta\right)-H\left(\theta_{b}-\Delta \theta\right)\right]}{\left[H\left(\theta_{b}\right) \times 2 \cdot \Delta \theta\right]}
$$

したがつて， $R b$ の単位は ${ }^{\circ} \mathrm{C}^{-1}$ である.（4)式に ( 3 ) 式を代入すると， $R b$ は ( 5 ) 式のようになる.

$$
R_{b}=\left[C_{\left(\theta_{b}+\Delta \theta\right) / \theta_{b}}-C_{\left(\theta_{b}-\Delta \theta\right) / \theta_{b}}\right] /[2 \cdot \Delta \theta] \cdots \cdots(5)
$$

$R b$ の值の表示法として, $R_{30.5}$ や $R_{30,10}$ を用いるが, 前者は $\theta_{b}: 30, \Delta \theta: 5$ の $R b$ の值を, 後者は $\theta_{b}: 30$, $\Delta \theta: 10$ のそれを示す.

4 ) 水温係数 $\overline{R b}\left[{ }^{\circ} \mathrm{C}^{-1}\right]: 1$ 実験に打いて, 2 条 件以上のデータがある場合には，（６)式を用いて各 条件の $R b$ の平均值 $\overline{R b}$ を算出し，この值をこの実 験の水温係数とした.

$$
\overline{R b}=\frac{1}{m} \sum_{i=1}^{m} R b^{(i)}
$$

5 ) 平均水温係数 $K b\left[{ }^{\circ} \mathrm{C}^{-1}\right]$ : 各実験の $R b$ や $\overline{R b}$ の值はかなりばらついているので，類似条件の実験 の結果をグルーピングして評価するため, ( 7 )式を 用いて各グループの $K b$ を算出した。

$$
K b=\frac{1}{n} \sum_{j=1}^{n}\left(R b^{(j)} \text { or } \overline{R b^{(j)}}\right)
$$


したがつて，一般論として，Kbの值の確からしさは， $R b$ や $\overline{R b}$ のそれより高いものと考えられる.

6 ) 水温補正式: 製鉄所の冷却水の温度 $\theta_{w}$ は, 特別 なケースを除き，10-50 Cの範囲内にある。また，特定 の製鉄所を対象にすると， $\theta_{\boldsymbol{w}}$ の変動範囲は，年間を通 して (短期的変動を含めても)，10-20 $\mathrm{C}$ 以内である. この程度の変動範囲内では， $\theta_{w}$ と $H$ との関係を 1 次式 で近似してもよい. したがつて, 水温 $\theta_{1}\left(=\theta_{b}-\Delta \theta\right)$ と $\theta_{2}\left(=\theta_{b}+\Delta \theta\right)$ との範䎴内で, $\theta_{x}$ と $H\left(\theta_{x}\right)$ との関 係を 1 次式で補完し, 水温補正式を(8)式のように定 義した。

$$
H\left(\theta_{x}\right)=H\left(\theta_{b}\right)\left[1+(R b, \overline{R b} \text { or } K b) \cdot\left(\theta_{x}-\theta_{b}\right)\right] \cdots \cdot(8)
$$

\section{3. 解 析 結 果}

\section{$3 \cdot 1$ 各実験の水温係数}

水温係数 $R b$ の值を概観するため, 各実験の実験範囲 内の $R_{\theta b .5}$ の値を Fig. 1 に亦す。この炏から，

1 ) すべての実験の $R_{\theta b, 5}$ の符号は負であること，す なわち，すべての実験に拈いて， $\theta_{w}$ の上昇につれて $H$ は減少すること，

$2)$ すべての実験の $\left|R_{\theta b .5}\right|$ の值は, $0.005-0.04^{\circ} \mathrm{C}^{-1}$ の範网内に存在すること, すなわち, $\theta_{w}$ が $\pm 1{ }^{\circ} \mathrm{C}$ 変動 すると，Hは干(0.5-4)\% 変動すること，

3 ) 解析の企対象範囲である $\theta_{b}: 20-40$ に対忍する $\left|R_{\theta_{b .5}}\right|$ の值は, 0.005-0.03の範讲内に存在すること, $4)$ ミル实験の $\left|R_{\theta b, 5}\right|$ の值は, ラボ実験のそれよ

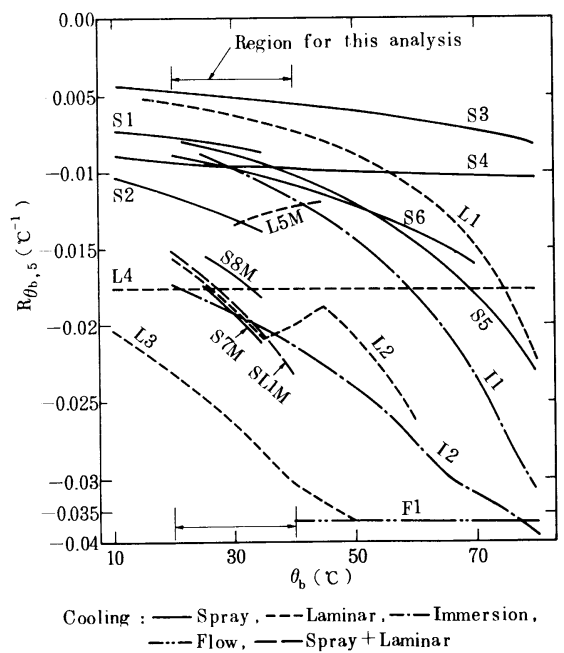

Fig. 1. Relation between basic water temperature, $\theta_{b}$, and coefficient of water temperature, $R_{\theta_{b}, 5}$, in several modes of water cooling.
り大きいこと $\left(\theta_{b}: 20-40\right)$,

5) $\left|R_{\theta b, 5}\right|$ の值は $\theta_{b}$ の上昇につれて増大すること, すなわち， $\theta_{w}$ の上昇につれて $H$ の減少割合は増大する こと,

6) $\left|R_{\theta b, 5}\right|$ の值は, 同じ冷却法でも, 各実験間で 大幅に相違していること，

がわかる。また，図示はしないが，| $\left|R_{\theta_{b, 10}}\right|$ の值と特 性は，上記 1$)$ ないし6）とほぼ同じである。

\section{$3 \cdot 2$ 各実験の冷却能力比}

各実験の冷却能力比 $C_{\theta_{x} / \theta_{b}}$ の例として, $C_{\theta_{x} / 30}\left(\theta_{b}\right.$ : 30, $\left.\theta_{x}: 20-40\right)$ の值を Fig. 2 に示す.この四から,

1 ）各実験の $C_{\theta_{x} / 30}$ の值は, $\theta_{x}$ の上昇につれて単䛇 に減少すること，すなわち，Hは $\theta_{x}$ の上昇につれて単 調に減少すること，

2) $C_{\theta_{x} / 30}$ の值は各実験間で大幅に相違しているこ と,がわかる。また，脳示はしないが， $C_{\theta_{\boldsymbol{x}} / 20}$ と $C_{\theta_{\boldsymbol{x}} / 40}$ の值と特性は，上記 1 ）と2）とほぼ同じである.

Fig. 2 では, 各種条件と $C_{\theta_{x} / 30}$ との関係がわかりに くいので, 各種条件ごとに $C_{\theta_{x} / 30}$ の平均值 $\bar{C}_{\theta_{x / 30}}$ を求 め, Fig. 3 に示す.この図から,

3) $\left|\vec{C}_{\theta_{x / 30}}\right|$ の変化量は, $0.01-0.02 /{ }^{\circ} \mathrm{C}-\theta_{w}$ であ ること,すなわち， $\theta_{w}$ が $\pm 1{ }^{\circ} \mathrm{C}$ 变動すると，Hの值は 干 (1-2)\% 変動すること,

4 ）ミル実験とラボ実験の $\left|\bar{C}_{\theta_{x} / 30}\right|$ の值を比較する と，ミル>ラボであること，

5 ) ラミナ冷却とスプレー冷却の $\left|\bar{C}_{\theta_{x} / 30}\right|$ の值を比 較すると，ラミナ>スプレーであること，

がわかる.すなわち，4）と5）は， $\theta_{w}:$ 20-40の範囲

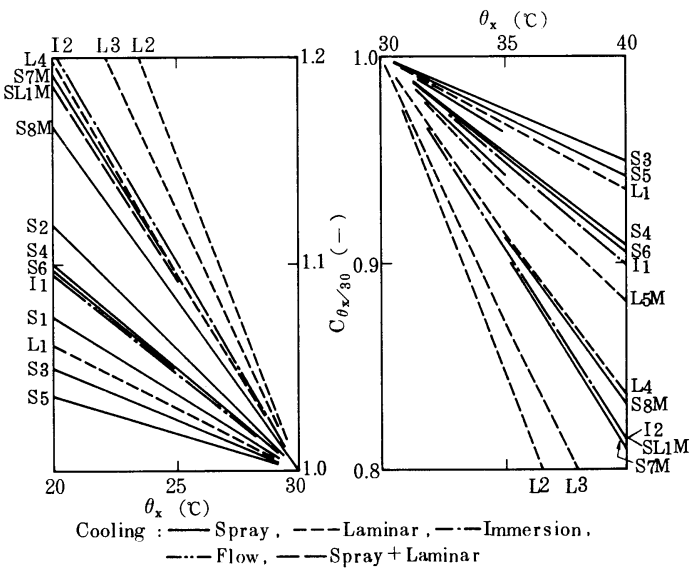

Fig. 2. Example of cooling capacity ratio, $C_{\theta_{x} / 30}$, in several modes of water cooling.in which 30 and $\theta_{x}$ are basic and arbitrary water temperature. 


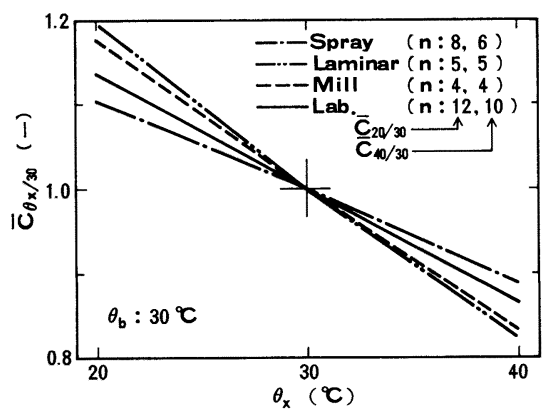

Fig. 3. Values of average cooling capacity ratio, $\bar{C}_{\theta_{x} / 30}$. in which 30 and $\theta_{x}$ are basic arbitrary water temperature, and $n$ is a number of data.

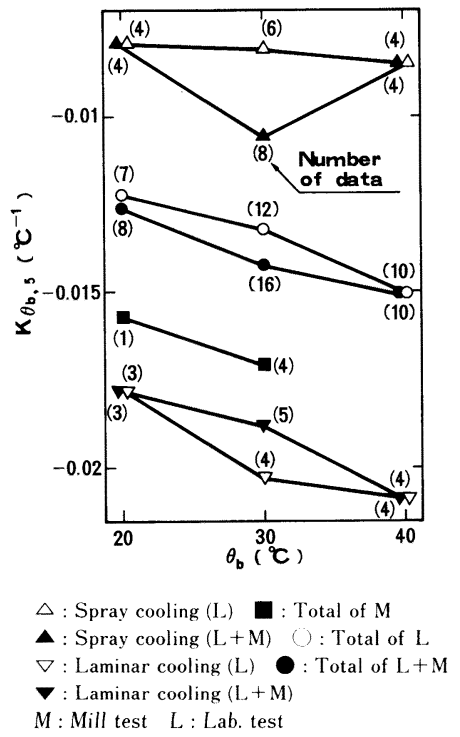

Fig. 4. Relation between basic water temperature, $\theta_{b}$, and average coefficient of water temperature, $K_{\theta_{b}, 5}$.

内では， $\theta_{w}$ の変動に対する $H$ の変動割合が，それぞれ ミル>ラボ，拉よびラミナ>スプレーであることを示し ている.

\section{$3 \cdot 3$ 平均水温係数の值}

Fig. 2 に示すように，各実験の泠却能力比 $C_{\theta_{x} / 30}$ の 值は, 大きくばらついている $(4 \cdot 1$ 参照).これらのデー 夕から算出した $K b$ の值を Fig. 4 に示す。この汹から,

1) $K_{\theta b, 5}$ の值は, $\theta_{b}: 20-40$ の範井内では, 一 $0.008^{-}-0.021^{\circ} \mathrm{C}^{-1}$ であること,

$2)$ ミルの標準的水温である $\theta_{b}: 30$ に対応する $\left|K_{30.5}\right|$ の值は, 0.013-0.017であること, すなわち, $\theta_{w}$ が $\pm 1{ }^{\circ} \mathrm{C}$ 変動すると, $H$ が干 (1.3-1.7)\% 変動する
こと,

$3)\left|K_{\theta b, 5}\right|$ の值は, $\theta_{b}$ の上昇につれて漸増すること,

4 ) ラミナ冷却とスプレー冷却の $\left|K_{\theta_{b, 5}}\right|$ の值を比 較すると, ラミナ>スプレーであること,

5 ) ラボ実験とミル実験の $\left|K_{\theta b, 5}\right|$ の值を比較する と,ミル>ラボであること，

がわかる.なお，3）の現象は $3 \cdot 1$ 節の 5 ）と，4） と 5 ）の現象は，それぞれ $3 \cdot 2$ 節の 4 ）と 5 ）のそれ と同じであることを示している。

\section{4. 考察}

\section{$1 \cdot 1$ 水温係数のばらつき}

Fig. 1 と 2 に示すように, 水温係数 $R b$ や冷却能力比 $C$ の值は，同じ冷却法でも各实験䦌で大きく相違して いる. $C$ と $R b$ は，それぞれ（3)式と（5) 式に示すよ うに，基準水温 $\theta_{b}$ と任意水温 $\theta_{x}$ に対忍する冷却能力 $H\left(\theta_{b}\right)$ と $H\left(\theta_{x}\right)$ の比として趛義しているから，各実 験の $H$ の変動の影響はほとんど受けないものと考えら れる.しかし，解析結果によると， $H$ の変動が $R b や C$ の值に影響しているようなので，Hの変動について検 討する.

$H$ の変動の主要原因として, (1)武料表岶のスケール (鉄酸化物) 厚み，(2)試料の表酒温度，(3)墳射水荲など の変動が考えられる。

1）スケールについて: 表面に断熱简（熱伀導率 $\lambda$ が試料のそれより小さい物質) が付着している高温試料 を水冷する場合，最小膜沸騰過熟度（クエンチ占） $T q$ が上昇すること，すなわち $H$ が増人することは，多く の研究者によつて明らかにされている12)-14). 鋼材とス ケールの入の比（鋼材/スケール）は10 程度なので, スケールは断熱層として作用する（入は铜材：約 30 $\left(600^{\circ} \mathrm{C}\right)$, スケール : 1-4 kcal $\left./ \mathrm{m} \cdot \mathrm{h} \cdot{ }^{\circ} \mathrm{C}\right)$. 各实験のスケー ル厚みは不明であるが，著者らの経験によると，スケー ル㫗みは $10^{0}-10^{2} \mu \mathrm{m}$ オーダーと考えられる.

KIKUCHI ら ${ }^{12)}$ の閒欠性湖液接触モデルによる計算によ ると（飽和プール水浸漬冷却，銀試料），断熱層厚みと

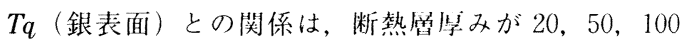
$\mu \mathrm{m}$ の場合，それぞれテフロン：410，560，730，利熱 塗料: $300,340,380^{\circ} \mathrm{C}$ である(入はテフロン：約 0.22 , 耐熱塗料: 約 1.03)。このように，断熱層厚みが増大寸 ると，Tqが上昇するから，冷却は促進される，したが つて，スケール厚みの変動は，Hの変動に少く影響し ているものと考えられる.

2 ) 試料表面温度 $\theta_{s}$ について：的で表小されている 実験については， $\theta_{s}: 500-700^{\circ} \mathrm{C}$ 䦌のデー夕を、試料内 
部温度のそれについては, 初期温度 $\left(800-1000^{\circ} \mathrm{C}\right) \rightarrow$ $500^{\circ} \mathrm{C}(1 / 2 \mathbf{t})$ 䦌のデー夕を解析に採用した。したがつ て, 後者の $\theta_{s}$ には, 初期温度から $200-450^{\circ} \mathrm{C}$ までの範 曲が含まれているものと推走される。水冷の場合， $\theta_{s}$ が熱伝達に蚛く影蚃するから， $\theta_{s}$ の範讲の差は $H$ の值 に強く影響しているものと考えられる.

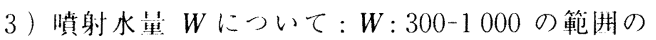
デー夕を解析に採用したが，熱伝達量は $W$ に比例する から，Wの着は $H$ の佃に䖝く影響しているものと考え られる。

以上のように, 器滥锁材を水冷する場令, $H$ の值は 種々の荌纳に影響されるから,これらの要因が $R b や C$ の值の変動に影帮している川能性がある.

\section{$1 \cdot 2$ 水温係数の特性}

高温鋼材を水冷する場苓， $\theta_{w}$, の上昇につれて $H$ が減 少する理山について検封する.

(1)冷却水の显熱減少の効果

离温試料に梇射された水は, 武料から熱を奪つて昇温 し, その一部は父化する. 水温上:昇の場令, 伝達熱量 $q a$ と $\theta_{u}$ との䦌には $(9)$ 式の関係がある.

$$
q a=h \cdot\left(\theta_{s}-\theta_{w}\right)
$$

$h$ と $\theta_{s}$ が一起の埸众， $q a$ は $\theta_{w}$ の上䄯につれて減少し， その減少割令，すなわち $R b$ の値は， $\theta_{s}: 600$ および $\theta_{u}$ $: 30^{\circ} \mathrm{C}$ とすると, - 1/570 ( $\left.R b=-0.00175\right)$ である.

-方, 気化する場令, 伀達熟量 $q v$ と $\theta_{w}$ との間には (10) 式の関係がある。

$$
q V=c \cdot\left(T b-\theta_{w}\right)+H L
$$

ここで, 水の比熱 $c: 1 \mathrm{kcal} / \mathrm{kg} \cdot{ }^{\circ} \mathrm{C}$, 水の沸点 $\mathrm{Tb}$ : $100^{\circ} \mathrm{C}$ および水の父化潜熱 $H L: 540 \mathrm{kcal} / \mathrm{kg}$ とすると, (10)式は（11)式になる。

$$
q V=\left(100-\theta_{w}\right)+540
$$

したがつて, $q v$ は $\theta_{w}$ の!昇につれて減少し, その減少 制介は - 1/610 $(R b=-0.00164)$ である.

上記の結果によると,どちらの場令にも， $R_{30,5}$ の值は， 約 -0.0017 となり, Fig. 1 や 4 に示す $R_{30.5}$ の值（一 0.01--0.02) より 1 桁小さい. したがつて, $\theta_{w}$ の上 昇による水の顕熱減少だけでは， $R b$ の值を説明するこ とはできない.

\section{( 2 ) 蒸気膜カバー摔の効果}

去幅試料を $W: 300-1000$ の水量で冷却する場命, 武 料のほぼ全泊が冷却水でおおわれる。試料表面に形成さ れる蒸知膜の状態は各種条作に影響されるが，マクロ的 に見れば，武料表洦を掞㧍う蒸気膜の面積割合（蒸気膜 カバー率 $F C$ ）は，他の条件が同じであれば， $\theta_{w}$ の上 莽につれて增大するはずである。活液接触部（伝導伀熱
と核沸騰伝熱）の熱流束 $q c$ は，膜沸騰部の熱流束 $q f$ より 1 桁程度大きい $\left(\theta_{s}\right.$ : 約 $600^{\circ} \mathrm{C}$ の場令， $q c: 1.3 \times$ $\left.10^{6}, q f: 1.2 \times 10^{5} \mathrm{kcal} / \mathrm{m}^{2} \cdot \mathrm{h}\right)^{12}$. 試料加冷却水へ伝 達する全熱流束 $q t$ は，(12)式のようになる.

$$
q t=q f \cdot F C+q c \cdot(1-F C)
$$

ここで, $q c / q f \doteqdot 10$ とすると, (12)式は (13)式になる. $q t=q c \cdot[F C / 10+(1-F C)]=q c \cdot(1-0.9 \cdot F C)$

したがつて $F C$ が $1 \%$ 変動すると， $q t$ は $0.9 \%$ 変動す る. $\theta_{w}$ と FC との対仙関係は不明だが， $\theta_{w}$ の $\pm 1 \%$ の 変動によつて，FCが士 (1-2)\%変動するものと仮是す ると, $R b$ の值は $-0.009--0.018^{\circ} \mathrm{C}^{-1}$ となる。この 值は, Fig. 1 や Fig. 2 の值とほほ同じである.

以上の検討結果から， $R b$ の值への $F C$ 变動の奇与率 は，水の顕熱変動のそれより火きいことがわかる．たと えば, $\theta_{w}: 30^{\circ} \mathrm{C}$ の場会, 前者の寄与率は 80-90\%, 後者 のそれは 10-20\%と推分される。

\section{$1 \cdot 3$ 水温係数の值の特性}

(1) 水温係数の計算值

Table 3 に示すように, 各実験の実験式は, (14), (15) または(16)式で表されている.

$$
\begin{aligned}
& H\left(\theta_{x}\right)=a+b \cdot \theta_{x} \\
& H\left(\theta_{x}\right)=a+b \cdot \theta_{x}+c \cdot \theta_{x}{ }^{2}
\end{aligned}
$$

$\log \left[H\left(\theta_{x}\right)\right]=a+b \cdot \theta_{x}$

$a, b, c$ : 定数, $\theta_{x}:$ 任意水温

(14)式と（16)式について， $\theta_{x}: 10$ と $50^{\circ} \mathrm{C}$ に刘㣽る $H$ をそれぞれ $H 10$ および $H 50$ とすると, $R b[=$ $\left.\left(d H / d \theta_{x}\right) / H\right]$ は，(17) または（18)式になる。

(14) 式

$$
: R b=[1-k] /\left[40(1.25 k-0.25)+(1-k] \theta_{x}\right]
$$

(16) 式

$$
: R b=-[\ln (10)] \cdot[(\log (k)) / 40]
$$

これらの式中の $k$ は, $H 10$ と $H 50$ の比 $(H 10 / H 50)$ である。（17）と（18)式から計算した $R b$ の值を Fig. 5 に示す。この网から，

$1 ）(14)$ 式の場合， $|R b|$ の值は， $\theta_{x}$ の上昇につれ て増大すること，すなわち， $\theta_{x}$ の上昇につれて $d H / d \theta_{x}$ は一定だが, $H$ が減少するため $|R b|$ は増大すること,

2 ) (16)式の場合, $|R b|$ の值は， $\theta_{x}$ の影響を受け ず一走值であること，

3) $|R b|$ の值は, $k$ に比例して増大すること, す なわち， $\theta_{x}$ の上昇に対心する $H$ の減少割合が大きいほ ど, $|R b|$ の值は大きいこと,

$4 ） k: 1.5-2.0$ の場命， $\theta_{x}: 30$ に対応する $|R b|$ の 


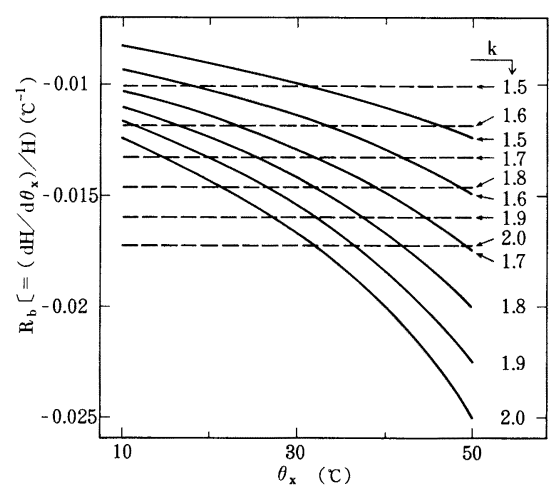

- : $\mathrm{E}_{\mathrm{q}},(17)-\longrightarrow: \mathrm{E}_{\mathrm{q}},(18)$

k : Cooling capacity ratio $[\mathrm{H}(10) / \mathrm{H}(50)]$

Fig. 5. Relation between water temperature, $\theta_{x}$, and coefficiet of water temperature, $R b$, which is calculated from the equation (17) and (18).

値は, $0.010-0.018^{\circ} \mathrm{C}^{-1}$ の範囲内に存在すること, が わかる.

Fig. 4 の $K_{\theta b, 5}$ の值と Fig. 5 の $R b$ の值を比較する と, 各実験の $k$ の值は 1.5-2.0 の範囲内に存在するこ と，すなわち， $\theta_{x}$ が 10 から $50^{\circ} \mathrm{C}$ まで上昇すると， $H$ の值は 33-50\% 程度減少することがわかる.

\section{(2) 水温係数の測定値}

$\theta_{b}$ が 30 の場合, Fig. 1 によると, 各実験の $R_{\theta b, 5}$ の 值は, 一 0.005-0.026であり, Fig. 4 によると, 全実験, ミル実験およびラボ実験の $K_{30.5}$ の值は，それぞれ $0.014(n: 16),-0.017(n: 4)$ および $-0.013(n: 12)$ である. Fig. 5 によると,これらに対忍する $k$ の值は, 全実験 : 約 1.8 , ミル実験 : 約 1.9 およびラボ実験 : 約 1.7 ある。

著者らは, 従来から $K_{30,5}$ や $K_{30,10}$ の值として, 一 0.015 を用いてきたが $\left(\theta_{w} \pm 1^{\circ} \mathrm{C}\right.$ の変動に対し， $H$ は $\mp 1.5 \%$ 変動), この值は, 全実験の $K_{30,5}$ の値に近い. 解析結果によると, 冷却条件によつて, $R b$ の值は相違 するようだが，熱間压延鋼材を水冷する場合， $\theta_{s}>$ 約 500 で，かつ $W: 300-1000$ の場合， $K_{30,5}$ の值は, 0.014- - 0.017 の範囲内に存在するものと考えられる.

$\left|R_{30,10}\right|$ と $\left|K_{30,10}\right|$ の值は, それぞれ $\left|R_{30,5}\right|$ と $\left|K_{30,5}\right|$ のそれより若干大きいが, 実用上両者の值は ほほ同じである，とみなしてよい。

(3) 水温係数の水温依存性

Fig. 1 によると, 各実験の $\left|R_{\theta b, 5}\right|$ の值は, $\theta_{b}$ の上 昇につれて, (1) $\theta_{b}: 20-40$ の範囲内では漸増し, (2) $\theta_{b}>$ 約 $50^{\circ} \mathrm{C}$ の範囲では増大している. (2)の場合, $\theta_{b}$ が沸点
Table 4. Comparison of coefficient of water temperature, $R_{\theta b, 5}$, at stagnation zone with water flow zone in laminar and water flow cooling.

\begin{tabular}{|c|c|c|c|}
\hline \multirow{2}{*}{$\left(\begin{array}{c}\theta_{b} \\
\left({ }^{\circ} \mathrm{C}\right)\end{array}\right.$} & \multirow{2}{*}{ Exp. No. } & \multicolumn{2}{|c|}{$R_{\theta b .5}\left({ }^{\circ} \mathrm{C}^{-1}\right)$} \\
\hline & & Stagnation zone & Water flow zone \\
\hline \multirow{2}{*}{30} & L2 $(\operatorname{Rod})$ & $-0.0191(r=0)$ & $-0.0418(r=10)$ \\
\hline & L4 (Curtain) & $-0.0177(l=0)$ & $-0.0183(l=50)$ \\
\hline \multirow{3}{*}{40} & $\mathrm{~L} 2$ & -0.0201 & -0.0319 \\
\hline & $\mathrm{L} 4$ & -0.0177 & -0.0183 \\
\hline & $\mathrm{F} 1$ & & $-0.0373(l=100+200)$ \\
\hline
\end{tabular}

に近づくと，蒸気膜が生成されやすくなるため，Hが 急滅する現象に対応しているものと考えられる.

Fig. 1 によると, S4, L4 および F1 の $\left|R_{\theta b .5}\right|$ の值 は, $\theta_{b}$ の影響を受けない. L4 と F1 の場合, 実験式が (16)式の形のため, $\left(d H / d \theta_{w}\right) / H$ は一走となる ((18)式 参照)。また, L5M の $\left|R_{\theta b, 5}\right|$ の値は, $\theta_{b}$ の上昇につ れて漸減しているが, これは, 奏験の $\theta_{w}$ 範用が狭いた めに現れた現象と考えられる（原論文によると $\theta_{w}:$ $45^{\circ} \mathrm{C}$ で実験)。実験式が (14)式の形の場令， $\left|R_{\theta b, 5}\right|$ の值は， $\theta_{b}$ の上昇につれて増大することになる（(17) 式参照).

\section{(4) 冷却法と水温係数}

Fig. 4 によると，ラミナ冷却の $\left|K_{\theta b, 5}\right|$ の值は，スプ レー冷却のそれより大きい。凷冷却法の噴射水流の状態 は大きく相違している，すなわち，スプレーでは，冷却 水は微小水滴に分散され，広範同にほほ均一に噴射され るのに対し，ラミナでは，冷却水の分散は抑えられ太い 整流状態のまま特定の場所に集中的に墳射される。 ラミ ナの場合, 試料へ衝突した冷却水は試料上を流れるから, このゾーンでは流水冷却になる。静止試料を用い，水流 衝突ゾーンと流水ゾーンの両方で $H$ を測定したL2 (ロッドラミナ) と L4 (カーテンラミナ), および流水 冷却 $(\mathrm{F} 1)$ の $R_{\theta b, 5}$ の值を Table 4 に亦す。この表に よると, ラミナ冷却の $\left|R_{\theta b .5}\right|$ の值は, 流水ゾーン> 衝突ゾーンであり，また流水冷却の $\left|R_{40,5}\right|$ の值は 0.0373 と大きい. したがつて, 流水ゾーンの $|R b|$ の 值は，衝突ゾーンのそれより相対的に大きいものと考え られる(著者らにはこの現象の理由は不明である).

ラミナ冷却の全熱伝達には, 衝突ゾーンと流水ゾーン のそれぞれの熱伝達が含まれている。これに対し，スプ レ一冷却では水滴が泠却面全面に衝突する。したがつて, ラミナ冷却の $|R b|$ の值がスプレ一冷却のそれより相 対的に大きくなるものと考えられる. 
(5) ミル尖験の水温係数

Fig. 4 に亦すように, $\left|K_{30,5}\right|$ の值は, ミル実験 $>$ ラボ実験である。解析に用いた冷却法の内訳は，ミル実 験（上面冷却）：スプレー 50\%，ラミナ $50 \%$ ，これに対 し，ラボ实験（一部下面冷却を含む）：スプレー $50 \%$, ラミナ $33 \%$ ，浸漬 $17 \%$ である。したがつて，両者の $K b$ に対する冷却法の南与率はほぼ等しいものと考えら れる.

ミルで製造される鋼极の幅は，1-5 $\mathrm{m}$ と広いため，上 面冷却の場令，ラミナでもスプレーでも全熱伝達に対す る流水冷却の寄与率は，ミル実験>ラボ実験である。こ の垷象が， $|K b|$ の値が，ミル実験>ラボ実験になる 原因の一つと考えられる. ROT 冷却の場合（ミル実験 のうち $75 \%$ はROT), 鋼材は什上げ圧延の直後に水冷 されるため, スケールの付着量は, ラボ試料のそれより 少ない。 スケールの付着量が $R b$ に及ぼす影響は不明だ が (4・1 参照)，この現爱もミルの $|K b|$ の值の增大原 因の-...つになつているのかも知れない.

著者らは，哀い間種々のミル（主にROT と厚板）の 冷却制御式に $K_{30,5}$ や $K_{30,10}$ の值として, $-0.015^{\circ} \mathrm{C}^{-1}$ を使用してきた。この值を採用した結果，ミルの短期的 休止などによつて $\theta_{w}$ が急変した場合でも，ROTでは 卷取り温度の的中率の低下を, 厚板では变形 ( $\mathrm{C}$ 反り) の増大を防归:することができた.この事実を考虑すると， 解析で得られたミル $(n: 4)$ の $K_{30.5}$ と $K_{30.10}$ の值 0.0171 は真実に近いものと考えられる. 以上のような 理由から，高温の㷇延鋼材を対象にする場合（主に ROTと麽板)， $K_{30,5}$ と $K_{30,10}$ の值は, $-0.015-$ 0.018 の範井内に仔在するものと考えられる.

\section{5. 結言}

鋼材の TMCP 用水冷を対象にして, 水温 $\theta_{w}$ が冷却 能力 $H$ に及ばす影響を, 著者らのデー夕と公開文献の デー夕を用いて解析した。解析に際しては，Hに及ぼ す $\theta_{w}$ の影響を表す水温係数 $R b\left[{ }^{\circ} \mathrm{C}^{-1}\right]$ を, $R b=[H$ $\left.\left(\theta_{b}+\Delta \theta\right)-H\left(\theta_{b}-\Delta \theta\right)\right] /\left[H\left(\theta_{b}\right) \times 2 \cdot \Delta \theta\right]$ のように, 水温補正式を, $H\left(\theta_{x}\right)=H\left(\theta_{b}\right)\left[1+R b \cdot\left(\theta_{x}-\theta_{b}\right)\right]$ の ように起義した $\left(\theta_{b}\right.$ : 基準水温, $\theta_{x}$ : 任意水温, $\Delta \theta: \theta_{b}$ からの水温差 $\left[{ }^{\circ} \mathrm{C}\right], K_{b}$ : 平均水温係数 $\left.\left[{ }^{\circ} \mathrm{C}^{-1}\right]\right)$. 主要 結果は次のとおりである.

1) $R b$ の值は各実験の閏で大幅に異なるが, $R_{30.5}$ $\left(\theta_{b}: 30, \Delta \theta: 5\right)$ の值は, $-0.005--0.03$ の範囲内に 存在する。すなわち, 水温が $\pm 1{ }^{\circ} \mathrm{C}$ 変動すると, 冷却 能力は干 (0.5-3)\% 変動する.

$2) R_{30.5}$ の平均值は, 苹実験 : $-0.0143(n: 16)$,
ラボ実験 : $-0.0133(n: 12)$ ，およびミル実験 : 一 $0.0171(n: 4)$ である $(n:$ 実験数 $)$.

3 ) ミル（熱延 ROT，厚板熱処理設備など）の $R_{30,5}$ の值は, $-0.015--0.018$ と推定される.

4 ）各冷却法の $R_{30,5}$ の值を平均值で比較すると, ラ ミナ>スプレーである.

5) $\left|R_{\theta b, 5}\right|$ の值の多くは， $\theta_{b}$ の上昇につれて漸増 する，すなわち， $\theta_{b}$ が上昇すると，Hの減少割合は漸 増する。

本解析に際し，貴重なデー夕を利用させていただいた 各文献の著者に感謝致します。

\section{記 号}

$\theta_{w}, \theta_{b}, \theta_{x}$ :一般的, 基準および任意水温 $\left[{ }^{\circ} \mathrm{C}\right]$

$\Delta \theta: \theta_{b}$ からの水温差 $\left[{ }^{\circ} \mathrm{C}\right]$

$W:$ 噴射水流密度 $\left[1 / \mathrm{m}^{2} \cdot \mathrm{min}\right]$

$H:$ 冷却能力 $[-]$

$q:$ 熱流束 $\left[\mathrm{kcal} / \mathrm{m}^{2} \cdot \mathrm{h}\right]$

$h, \quad \bar{h}:$ 熱伝達係数 $\left[\mathrm{kcal} / \mathrm{m}^{2} \cdot \mathrm{h} \cdot{ }^{\circ} \mathrm{C}\right]$

$V:$ 冷却速度 $\left[{ }^{\circ} \mathrm{C} / \mathrm{s}\right]$

$C_{\theta_{\boldsymbol{x}} / \theta_{b}}$ : 冷却能力比 $[-]$

$C_{20 / 30}: \theta_{x}: 20, \theta_{b}: 30^{\circ} \mathrm{C}$ の冷却能力比の值 [- ]

$R b, \overline{R b}, K b, R_{\theta b, \Delta \theta}:$ 水温係数 $\left[{ }^{\circ} \mathrm{C}^{-1}\right]$

$R_{30,5}: \theta_{b}: 30, \Delta \theta: 5^{\circ} \mathrm{C}$ の水温係数の值 $\left[{ }^{\circ} \mathrm{C}^{-1}\right]$

$K_{30,5}: \theta_{b}: 30, \Delta \theta: 5^{\circ} \mathrm{C}$ の平均水温係数の值 $\left[{ }^{\circ} \mathrm{C}^{-1}\right]$

$k: \theta_{w}: 10$ と $50^{\circ} \mathrm{C}$ に対応する $H$ の比 $(H(10) / H(50))$

S, L, I, F : スプレー, ラミナ, 浸漬および流水冷却

\section{文献}

1 ) 福田敬爾, 三塚正志, 横倉照大, 梅野正紀: 材料とプロセ ス, 1 (1988), p. 1491

2 ) 三塚正志: 鉄と鋼, 54 (1968), p. 1457

3 ) 吉田秋登, 島田道彦, 清水亮, 三塚正志: 鉄と鋼, 52 (1966), p. 631

4) K. P. Korotkov, H. P. Mayorov, A. A. Skvortsov and A. D. Aкімеnкo: The Continuous Casting of Steel in Commercial Use (1960), p. 59 [Pergamon Press]

5 ) 国岡計夫, 杉山俊一, 神尾 寛: 鉄と鋼, 64 (1978) S 255

6 ) 白岩俊夫, 小林純夫: 鉄と鋼, 57 (1971), p. 485

7 ) 大友朗紀, 山口喜弘, 中尾正和, 水田篤男, 大砂 寛, 柚垣英則: 鉄と鋼, 66 (1980), S 955

8 ) 柳 謙一, 橋本律男, 槙原克己, 中村義満, 江口章介, 坂本 潤, 平井慎二: 三菱重.T技報, 20 (1983) 3, p. 352

9 ) 三宅祐史, 西出輝幸, 守谷正一, 池永孝雄, 井上利夫, 高木 清: 川崎製鉄技報, 10 (1978) 1, p. 58

10）三塚正志，福田敬爾：鉄と鋼, 63 (1977), p. 1008

11) 三塚正志, 福田敬爾: 鉄と鋼, 64 (1978), p. 70

12) $Y$. Kikuchi, $T$. Hori, $H$. YanagaWa and $I$. Michiyoshi: Trans. Iron Steel Inst. Jpn., 26 (1986), p. 576

13）淵沢定克, 奈良崎道治, 下山勇二郎, 武田信男: 精密機械, 46 (1980), p. 842

14）西尾茂文: 日本機械学会論文集（B 編), 51 (1985) 462, p. 582 